\title{
THE COURT OF CLAIMS AND THE WUNDERLICH ACT: TRENDS IN JUDICIAL REVIEW
}

\author{
JOSEPH SACHTER*
}

Lawyers faced with government contract controversies can easily find themselves in a hopeless quandary. If the matter cannot be settled administratively, the course of judicial review is a unique and unfamiliar one, with a vast number of pitfalls-pitfalls whose size and location seem to change with each new decision rendered by the Court of Claims. This article attempts to exhaustively chart the pitfalls and the course to be followed for effective handling of a review. It is an invaluable aid to the practitioner.

7 HE CONTROVERSY surrounding judicial review by the 1 Court of Claims of administrative decisions on government contract disputes has received a substantial amount of treatment in legal literature. ${ }^{1}$ The difficult, interesting, and provocative problems in this area have been extensively discussed, and many solutions to those problems have been proposed. ${ }^{2}$ While an analysis in a critical vein constitutes a serious temptation for any writer, that approach to the subject matter already wears a sufficient number of coats. This article assumes a more pragmatic cloak; it contents itself with an up-to-date analysis of what the law is, not what it

* LL.B. 1929, Syracuse University. Member, New York Bar. Special Counsel to State Department (AID), 1963-1964.

${ }^{1}$ See generally Cuneo, Determination of Government Contract Disputes, Prac. Law., March 1958, p. 54; Cuneo \& Crowell, Parallel Jurisdiction: If the Court of Claims Can, Why Not the Administrative Boards?, 33 FordHAM L. REv. 137 (1964); Kennedy, The Conclusiveness of Administrative Findings in Disputes Arising Under Government Contracts, 4 BAYLoR L. Rev. 160 (1952); Schultz, Wunderlich Revisited: New Limits on Judicial Review of Administrative Determination of Government Contract Disputes, 29 LAw \& Contemp. Prob. 115 (1964); Schultz, Proposed Changes in Government Contract Disputes Settlement: The Legislative Battle Over the Wunderlich Case, 67 Harv. L. REv. 217 (1953); Shedd, Disputes and Appeals: The Armed Services Board of Contract Appeals, 29 LAw \& Contemp. Prob. 39 (1964); Spector, Is It "Bianchi's Ghost"Or "Much Ado About Nothing"?, 29 LAw \& Contemp. Prob. 87 (1964); Speidel, Exhaustion of Administrative Remedies in Government Contracts, 38 N.Y.U.L. REv. 621 (1963); Note, 32 Geo. WAsh. L. Rev. 118 (1963); Note, 54 GEo. L.J. 644 (1966); Note, 39 N.Y.U.L. REv. 290 (1964); Note, 73 YALE L.J. 1408 (1964).

2See, e.g., Cuneo \& Crowell, supra note 1, at 168-72; Schultz, Wunderlich Revisited: New Limits on Judicial Review of Administrative Determination of Governmental Contract Disputes, 29 Law \& Contemp. Prob. 115, 134-36 (1964); Note, Geo. Wash. L. REv. 118, 124-25 (1963); Note, 54 GEO. L.J. 644, 672-79 (1966); Note, 73 Yale L.J. 1408, 1443-58 (1964). 
should be, and any prognostications which it may make will be based on the assumption that serious changes will not be made in the statutes or administrative procedures involved.

Despite the protestations of the preceding paragraph, however, a brief background of the area is necessary for the uninformed. reader. While it is said that when the Government enters into contracts it has rights and responsibilities similar to those of individuals, ${ }^{3}$ it should be pointed out that federal government contracts differ materially from private contracts. For one thing, the provisions of government contracts can hardly be said to emanate from a "meeting of the minds"; rather, the provisions are wholly dictated by the Government. "It is well known that anyone seeking a contract with the Government must be willing to agree to accept the contract drawn by the Government . . ."4 Additionally, the ordinary contract remedies would be intolerable in a government contract: the technical procedures and delays of litigation might cause economic havoc to a contractor whose credit may have been stretched to the limit in order to undertake the contract; and the Government cannot afford delays in completion of the contract. Hence, the use of some sort of arbitration procedure was inevitable.

Arbitration provisions in government contracts take the form of a standard "disputes" clause." This clause provides that all dis-

\footnotetext{
${ }^{3}$ Perry v. United States, 294 U.S. 330, 352 (1935).

- Utah Constr. \& Mining Co. v. United States, 168 Ct. Cl. 522, 530, 339 F.2d 606, 611 (1964), modified, 34 U.S. LAW WEEK 4440 (U.S. June 6, 1966), 1965 Duke L.J. 654.

"For example, the prescribed "disputes" clause for supply contracts, 41 C.F.R. $\S$ 1-7.101-12 (1965), reads as follows:

"(a) Except as otherwise provided in this contract, any dispute concerning a question of fact arising under this contract which is not disposed of by agreement shall be decided by the Contracting Officer, who shall reduce his decision to writing and mail or otherwise furnish a copy thereof to the Contractor. The decision of the Contracting Officer shall be final and conclusive unless within 30 days from the date of receipt of such copy, the Contractor mails or otherwise furnishes to the Contracting Officer a written appeal addressed to the Secretary. The decision of the Secretary or his duly authorized representative for the determination of such appeals shall be final and conclusive unless determined by a court of competent jurisdiction to have been fraudulent, or capricious, or arbitrary, or so grossly erroneous as necessarily to imply bad faith, or not supported by substantial evidence. In connection with any appeal proceeding under this clause, the Contractor shall be afforded an opportunity to be heard and to offer evidence in support of its appeal. Pending final decision of a dispute hereunder, the Contractor shall proceed diligently with the performance of the contract and in accordance with the Contracting Officer's decision.

"(h) This 'Disputes' clause does not preclude consideration of law questions in connection with decisions provided for in paragraph (a) above. Provided, That nothing in this contract shall be construed as making final the decision of any administrative official, representative, or board on a question of law."
} 
putes between the parties arising under the contract shall be decided by a specified government contracting officer, and that his decision will be final. Almost all government contracts now allow an appeal from the contracting officer's decision to some sort of administrative appeals board, but the "disputes" clause ordinarily states that work on the contract must continue pending such an appeal. This system of settling disputes is an expeditious one, and usually works to the advantage of both parties. A dissatisfied contractor may, however, wish to attack an unfavorable decision in the courts. ${ }^{6}$ He may bring suit in either the federal district courts or the Court of Claims, ${ }^{7}$ and the question which immediately arises is what type of control a court may then exercise over the controversy.

Resolution of this question has had a long history. The Supreme Court in 1878 upheld the validity of arbitral clauses which permitted one of the parties in the dispute to resolve $\mathrm{it}^{8}{ }^{8}$ and in 1950 the Court held that "disputes" clauses providing for finality of administrative decisions on questions of law precluded judicial review of such decisions. ${ }^{9}$ Close on the heels of this case came Wunderlich 7 . United States, ${ }^{10}$ holding that, absent fraud (conscious wrongdoing on the part of the government adjudicators), judicial review was likewise precluded on questions of fact.

In response to the furor caused by this case, Congress took a hand and liberalized the standards for judicial review of administrative decisions under government contracts by enacting the Wunderlich Act. ${ }^{11}$ This act permitted judicial attack on fact decisions upon

\footnotetext{
- Sovereign immunity was waived for contract claims against the Government by Tucker Act $\S 1$, ch. 359 , 24 Stat. 505 (now codified in 28 U.S.C. $\S \S 1346$ (a) (2), 1491 (1964)).

${ }^{2}$ Jurisdiction in the Court of Glaims is provided by 28 U.S.C. $\S 1491$ (1964). The District courts have concurrent jurisdiction to hear such cases where the amount involved does not exceed $\$ 10,000$ by virtue of 28 U.S.C. $\$ 1346$ (a) (2) (1964).

${ }^{8}$ Kihlberg v. United States, 97 U.S. 398 (1878).

- United States v. Moorman, 338 U.S. 457 (1950).

${ }^{10} 342$ U.S. 98 (1951).

1168 Stat. 81 (1954), 41 U.S.C. $\$ \S 321-22$ (1964):

" $N]$ o provision of any contract entered into by the United States, relating to the finality or conclusiveness of any decision of the head of any department or agency or his duly authorized representative or board in a dispute involving a question arising under such contract, shall be pleaded in any suit now filed or to be filed as limiting judicial review of auy such decisions to cases where fraud by such official or his said representative or board is alleged: Provided, however, That any such decision shall be final and conclusive unless the same is fradulent [sic] or capricious or arbitrary or so grossly erroneous as necessarily to imply bad faith, or is not sup. ported by substantial evidence."
} 
allegations that such decisions were (1) fraudulent, (2) arbitrary, (3) capricious, (4) so grossly erroneous as necessarily to imply bad faith, or (5) not supported by substantial evidence. The act further provided that no government contract shall contain a provision making final on a question of law the decision of any administrative official, representative, or board.

\section{I}

\section{The Basic Conflict Between the Supreme Court and the Court of Glaims}

The Court of Claims initially interpreted the Wunderlich Act as permitting trials de novo in actions to review administrative decisions. ${ }^{12}$ The circuit courts, on the other hand, were unanimous in construing the act as limiting judicial review to the administrative record. ${ }^{13}$ This confiict was seemingly resolved by the Supreme Court in United States v. Carlo Bianchi \& Co., ${ }^{14}$ which held that, except for fraud, judicial review of adverse administrative decisions falling within the scope of "disputes" clauses had to be tested for finality under the Wunderlich Act solely on the basis of the administrative record. ${ }^{15}$ The decision went on to say that an inadequate administrative record could, in an unusual situation, justify judgment against the Government, or the action for judicial review could be stayed or suspended to permit development by the agency involved of an administrative record which would be adequate for judicial scrutiny. ${ }^{16}$

The Court of Claims has not passively accepted this rebuff from the Supreme Court. Rather, the Court of Claims has relentlessly narrowed the Bianchi decision by a series of distinctions and refinements which, on the one hand, have given the contractor a wide scope of judicial review, but, on the other hand, present him with a tortuous path to follow to achieve that review. When a dispute

\footnotetext{
". . . No Government contract shall contain a provision making final on a question of law the decisions of any administrative official, representative, or board."

12 Volentine \& Littleton v. United States, 136 Ct. Cl. 638, 145 F. Supp. 952 (1956). See Fehlhaber Corp. v. United States, 138 Ct. C1. 571, 151 F. Supp. 817, cert. denied, 355 U.S. 877 (1957).

${ }^{13}$ See, e.g., Allied Paint \& Color Works, Inc. v. United States, 309 F.2d 133 (2d Cir. 1962), cert. denied, 375 U.S. 813 (1963); Hoffman v. United States, 276 F.2d 199 (10th Cir. 1960); Lowell O. West Lumber Sales v. United States, 270 F.2d 12 (9th Cir. 1959); Wells \& Wells, Inc. v. United States, 269 F.2d 412 (8th Cir. 1959).

16373 U.S. 709 (1963).

${ }^{15} I d$. at 714 .

${ }^{18}$ Id. at $717-18$.
} 
arises, therefore, it is essential for the contractor to move carefully through the steps necessary to effectuate his claim. These steps will be traced in the sections that follow.

\section{II}

\section{Administrative Proceedings}

\section{A. Exhaustion of Administrative Remedies}

The first decision to be made by the contractor is what he must do to obtain relief within the administrative framework. The ordinary course is to seek a final decision from the contracting officer, and if his decision is unsatisfactory, to appeal to the secretary or administrative appellate board provided for by the "disputes" clause of the contract. Failure to so exhaust these administrative remedies will result in dismissal of any later court action, at least when complete relief would have been available to the contractor under the terms of the contract. ${ }^{17}$

However, failure to exhaust administrative remedies has been held not to bar judicial relief in instances where the appeal procedure was inadequate or unavailable; ${ }^{18}$ where a contracting officer (or his equivalent) has refused or failed to make a decision within a reasonable time; ${ }^{19}$ where confusion and delay in pursuing the administrative processes have occurred; ${ }^{20}$ where further administrative proceedings would tend to "eat up the substance" of the claims; ${ }^{21}$ or where the contracting officer failed to carry out a decision by the appellate board in the contractor's favor. ${ }^{22}$ In general, the contractor must pursue his administrative remedies until he has no

${ }^{17}$ United States v. Joseph A. Holpuch Co., 328 U.S. 234 (1946); United States v. Blair, 321 U.S. 730 (1944). See generally Speidel, supra note 1.

If a contractor mistakenly applies for administrative relief, he is not thereafter estopped from suing in the Court of Claims for breach of contract. "A claimant is not restricted to a 'one-shot' or 'sudden death' attempt to obtain relief." Specialty Assembling \&. Packing Co. v. United States, 355 F.2d 554, 571 (Ct. Cl. 1966).

${ }^{18}$ E.g., Fireman's Fund Ins. Co. v. The U.S. Army LST 34, 132 F. Supp. 414, 415 (S.D.N.Y. 1955); Southeastern Oil Fla., Inc. v. United States, 127 Ct. Cl. 480, 484-85, 115 F. Supp. 198, 201 (1953).

${ }^{10}$ E.g., H. B. Zachry Co. v. United States, 170 Ct. Cl. 115, 122, 344 F.2d 352, 357 (1965); Oliver-Finnie Co. v. United States, 150 Ct. Cl. 189, 196.97, 279 F.2d 498, 503-04 (1960); Maxan Dress Corp. v. United States, 126 Ct. Cl. 434, 441-42, 115 F. Supp. 439, 443-44 (1953).

${ }^{20}$ E.g., Garod Radio Corp. v. United States, 158 Ct. Cl. 596, 600, 307 F.2d 945, 947 (1962); Reinking Lumber Co. v. United States, 151 Ct. Cl. 307, 311, 283 F.2d 527,529 (1960).

${ }^{21}$ E.g., Armstrong v. United States, 152 Ct. Cl. 731, 738, 287 F.2d 577, 580 (1961).

${ }^{22}$ E.g., C. J. Langenfelder \& Son v. United States, 169 Ct. Cl. 465, 474, 341 F.2d $600,604-05$ (1965). 
reasonable chance of obtaining relief, for whatever reason; but he is not required to act where it would be impossible or futile to do so.

If relief could not be granted by the administrative adjudicators-for example, where the claim is for breach of contract or in some other way does not arise under the contract-then there is no requirement of exhaustion. ${ }^{23}$

The attitude of the court toward the exhaustion requirement is illustrated by Universal Ecsco Corp. $v$. United States. ${ }^{24}$ Several of the contractor's claims in that case were clearly subject to the exhaustion rule. Nevertheless, the court held that since the plaintiff's major claims involved an alleged breach of the contract, "it would not be just or feasible to separate out this small part and require it to be heard administratively while the bulk of the case is tried in this court." 25

\section{B. Techniques During Administrative Proceedings}

Because the Wunderlich Act, as interpreted by Bianchi, provides for finality of administrative findings of fact which pertain to disputes arising under the contract, the contractor must make as strong a factual case as possible during the administrative adjudication.

A problem arises for the contractor, however, when a question of law is involved which requires certain factual determinations for its resolution. Should the contractor attempt to establish those facts before the administrative adjudicators, or may he wait until he reaches the Court of Claims? The answer to this question has apparently been given by the Court of Claims in Morrison-Knudsen Co. v. United States. ${ }^{26}$ In that case, the legal issue was a matter of contract interpretation, but complete relief could have been afforded the contractor under the contract. In view of the inherent complexities of the fact-law distinction and because the administrative boards frequently must decide questions of law to determine whether to grant relief, the court held that review should be limited to the record. This, it was felt, would "tend to improve the quality of the record" for review. ${ }^{27}$

\footnotetext{
${ }^{23}$ E.g., Commercial Cable Co. v. United States, 170 Ct. C1. 813, 822 (1965); Ekco Prods. Co. v. United States, 160 Ct. Cl. 75, 84, 312 F.2d 768, 773 (1963); see Compudyne Corp. v. Maxon Constr. Co., Gov'T Cont. Rep. If 80231 (E.D. Pa. Nov. 30, 1965).

${ }_{26} 170$ Ct. Cl. 809, 345 F.2d 586 (1965).

${ }^{25} I d$. at $813,345 \mathrm{~F} .2 \mathrm{~d}$ at 588 .

${ }^{20} 170$ Ct. Cl. 757, 345 F.2d 833 (1965).

${ }^{27}$ Id. at 763,345 F.2d at 837 .
} 
If the contractor desires any later judicial review to include independent fact-finding, he must also be careful not to submit to the administrative board factual disputes as within the scope of the "disputes" clause. If he does so, and a substantial amount of time, trouble, and expense are incurred by the agency in adjudicating the issue, he may be estopped from denying "that the factual determinations made by the administrative agency are within the scope of the 'Disputes' provision ...."28-even if in reality such determinations were outside the agency's jurisdiction. The contractor can escape this dilemma by consistently asserting throughout the administrative proceedings that his claim cannot be conclusively determined by the agency. ${ }^{29}$

\section{G. Appeals from Administrative Decisions}

The contractor who is dissatisfied with whatever treatment he has been accorded by the agency may, of course, institute suit in the Court of Claims. The notion, long entertained by lawyers and expressed by commentators prior to the passage of the Wunderlich Act, that only the contractor could "appeal" from an adverse decision has now been rejected by the court. While recognizing the practical difficulties of doing so as a regular matter of course, the court has declared in C. J. Langenfelder \& Son v. United States ${ }^{30}$ that the Government now has a corresponding right to appeal a decision against it, based on cases wherein administrative decisions favorable to the contractor were upset when found, upon judicial review, not to have met the standards set forth in the statute..$^{31}$

\section{III}

\section{Reversals in the Court of Claims}

How the Court of Claims disposes of a case will depend on a variety of factors. The court may affirm the agency's decision. If it reverses, it may be possible to do so without specifically or implicitly overturning some finding or holding of the agency. These instances will be discussed later in this article. ${ }^{32}$ More frequently,

${ }^{28}$ H. R. Henderson \& Co. v. United States, 169 Ct. Cl. 228, 245 (1965).

${ }^{20} \mathrm{~J}$. G. Watts Constr. Co. v. United States, 355 F.2d 573, 576 (Ct. Cl. 1966). Sec note 17 supra.

${ }^{30} 169$ Ct. Cl. 465, 341 F.2d 600 (1965); accord, Acme Process Equip. Co. v. United States, 347 F.2d 538, 543 (Ct. Cl. 1965).

${ }^{31} 169 \mathrm{Ct}$. Cl. at 477-78, $341 \mathrm{~F} .2 \mathrm{~d}$ at $607-08$.

${ }^{32}$ See part IV of this article. 
however, it will be necessary for the court to take action in direct opposition to that of the administrative adjudicators. The methods by which it can and cannot do so will be discussed below.

\section{A. Cases Squarely Within the Bianchi Holding}

The Court of Claims will follow Bianchi where the situation dictates that it do so. For example, if the judicial review by the court relates to the fact side of the administrative decision and the record shows it not to be afflicted with any of the vices set forth in the Wunderlich Act, the court will affirm. ${ }^{33}$ This will be true even in some cases where the agency determination is based on procedures which are less than desirable. ${ }^{34}$ The standard rule for review of an administrative record to determine whether it is sufficient "requires consideration of the materials presented by both sides, and of cross-examination as well as direct. . . . A scintilla is not sufficient, nor is it enough that some pieces of testimony, in isolation and by themselves, could be said to underpin the finding." 35 If these standards are not met, the court will hold that the administrative findings are not supported by substantial evidence and will upset them. ${ }^{36}$

If law questions are involved, or said to be involved, the court will also often affirm if satisfied that the legal conclusions are supported by the facts found in the record-that is, if "the facts clearly indicate no other interpretation could be made." 37

The court does not feel that it is compelled to review the entire administrative record. In $H . R$. Henderson \& Co. v. United States, ${ }^{38}$ the plaintiff proffered only those parts of the record which supported its position. The Government objected to this procedure, stating that it believed plaintiff was required to introduce the entire record; and while the court encouraged the Government to introduce other parts of the record to support its position, this

\footnotetext{
${ }^{33}$ E.g., National Concrete \& Foundation Co. v. United States, 170 Ct. Cl. 470, 475 (1965); General Bronze Corp. v. United States, 168 Ct. Cl. 176, 184, 338 F.2d 117, 122 (1964); T. C. Bateson Constr. Co. v. United States, 149 Ct. Cl. 514, 518 (1960). See also United States v. Seaboard Sur. Co., 339 F.2d 1, 2-3 (2d Cir. 1964).

${ }^{34}$ Allen \& Whalen, Inc. v. United States, 347 F.2d 992, 993-94 \& n.l (Ct. Cl. 1965).

${ }^{36}$ Farnsworth \& Chambers Co. v. United States, 346 F.2d 577, 582 (Ct. Cl. 1965).

${ }^{30}$ E.g., J. D. Hedin Constr. Co. v. United States, 347 F.2d 235, 246 (Ct. Cl. 1965); Blount Bros. Constr. Co. v. United States, 346 F.2d 962, 964 (Ct. Cl. 1965).

${ }^{37}$ American Marine Upholstery Co. v. United States, $170 \mathrm{Ct}$. Cl. 564, 573, 345 F.2d 577, 582 (1965).

${ }^{38} 169$ Ct. Cl. 228 (1965).
} 
offer was refused..$^{39}$ In view of the court's position on this matter, it is likely that the Government will not take this tack again.

\section{B. Waiver of Objection to De Novo Evidence}

Post-Bianchi decisions in the Court of Glaims have held that the legal principle of confinement to the administrative record is procedural or evidential, not jurisdictional. Failure of the Government to object to a de novo trial therefore constitutes a waiver. ${ }^{40}$ A review of these decisions shows that all of them involve instances where the Government's failure to object took place before the Bianchi decision was rendered. ${ }^{41}$ It seems unlikely that the Government will again fail to object or will participate in a de novo trial in a manner construable as a waiver unless satisfied that some advantage or benefit will thereby accrue to it.

Of course, both the right to object to de novo evidence and the ability to waive the objection belong to the contractor as well as the Government. ${ }^{42}$ The contractor must be on his guard to prevent a waiver if he desires review to be limited to the record. ${ }^{43}$

\section{Legal Questions}

The Wunderlich Act clearly provides that finality shall not attach to administrative decisions of law. This plunges the court and the parties before it into the wonderland of the law-fact distinction,

\footnotetext{
${ }^{39}$ Id. at 233-35.

${ }^{10}$ Construction Serv. Co. v. United States, 357 F.2d 973 (Ct. Cl. 1966); J. D. Hedin Constr. Co. v. United States, 347 F.2d 235, 246 (Ct. Cl. 1965); Gardner Displays Co. v. United States, 346 F.2d 585, 586 n.* (Ct. Cl. 1965); Acme Process Equip. Co. v. United States, 347 F.2d 509, 514 n.3 (Ct. Cl. 1965), cert. granted, 34 U.S.L. WEEK 3363 (U.S. April 25, 1966) (No. 1116); Kings Electronics Co. v. United States, 169 Ct. Cl. 433, 446, 341 F.2d 632, 640 (1965); Kaiser Indus. Corp. v. United States, 169 Ct. Cl. 3I0, 330, 340 F.2d 322, 333 (1965); National Presto Indus., Inc. v. United States, 167 Ct. Cl. 749, 755 n.2, 338 F.2d 99, 103 n.2 (1964), cert. denied, 380 U.S. 962 (1965); Commerce Int'1 Co. v. United States, 167 Ct. Cl. 529, 534-35, 338 F.2d 81, 85 (1964); Stein Bros. Mfg. Co. v. United States, 162 Ct. Cl. 802, 806, 337 F.2d 861, 862-63 (1963); WPC Enterprises, Inc. v. United States, 163 Ct. Cl. 1, 8, 323 F.2d 874, 878 (1963).

11 It is unclear, however, whether this was true in Construction Serv. Co. v. United States, supra note 40.

${ }^{22}$ See Gardner Displays Co. v. United States, 346 F.2d 585, 586 n." (Ct. Cl. 1965); Acme Process Equip. Co. v. United States, 347 F.2d 509, 514 n.3 (Ct. Cl. 1965), cert. granted, 34 U.S.L. WEEK 3363 (U.S. April 25, 1966) (No. 1116); National Presto Indus., Inc. v. United States, I67 Ct. Cl. 749, 755 n.2, 338 F.2d 99, 103 n.2 (1964), cert. denied, 380 U.S. 962 (1965).

43 The contractor must also beware of the possibility of waiving his right to ad. mission of de novo evidence. Terminal Constr. Corp. v. United States, Gov'T CoNT. REP. If 73059, at 63699 \& n.8 (Ct. Cl. 1965).
} 
a land the geography of which it is impossible to chart. ${ }^{44}$ Indeed, the Court of Claims frequently admits openly that the distinction is a knotty one; ${ }^{45}$ the court recently denominated its decisions in this area as "foray[s] . . . into the furrowed field of fact-law distinction ...." A6 And it must be admitted in all candor that it is not beyond the court to adjust the line between fact and law to fit the needs of the case. ${ }^{47}$

The advantage to the contractor of convincing the court that a question of law rather than of fact is at issue is two-fold: the court will not be bound by the substantial evidence rule, and de novo evidence may perhaps be introduced.

Clearly, the two most productive courses open to the contractor which may lead to the conclusion that an issue is a legal one are to claim that a breach of the contract is involved or that the question is one of interpretation of the contract. Both of these courses will avoid the finality rule; ${ }^{48}$ whether they will permit de novo evidence to be introduced is another matter.

Where the contractor sues for unliquidated damages allegedly caused by a breach of the contract on the Government's part, the court has clearly held, in Utah Constr. \& Mining Co. v. United States, ${ }^{40}$ that it may determine the facts de novo, even though the same facts have already been found by the agency in an earlier adjudication under the "disputes" clause. ${ }^{50}$ The basis for the majority decision was that the dispute arose outside of the contract and was one over which neither the contracting officer nor the administrative review agency had jurisdiction.

\footnotetext{
"See River Constr. Corp. v. United States, 159 Ct. Cl. 254, 262-65 (1962); 4 DAvIs, ADMINISTRATIVE LAW TREATISE $§ 30.01$ (1958); Schwartz, Judicial Review of Administrative Action: Mixed Questions of Law and Fact, 50 GEo. L.J. 684 (1962); Note, 54 GEo. L.J. 644, 660-63 (1966); Note, 39 N.Y.U.L. REv. 290, 301-14 (1964).

st "The distinction between factual and legal questions is fraught with many diffculties for the courts, as well as for the administrative boards." Morrison-Knudsen Co. v. United States, 170 Ct. Cl. 757, 762, 345 F.2d 833, 837 (1965).

${ }^{\circ}$ Chase \& Rice, Inc. v. United States, 354 F.2d 318, 321 (Gt. Cl. 1965).

${ }^{47}$ See text accompanying notes $58-73$ infra.

${ }^{8}$ E.g., T. F. Scholes, Inc. v. United States, 357 F.2d 963 (Ct. Cl. 1966); (interpretation); Tufano Contracting Corp. v. United States, 356 F.2d 535, 538 n.9 (Ct. Cl. 1966) (interpretation); J. G. Watts Constr. Co. v. United States, 355 F.2d 573, 576 (Ct. Cl. 1966) (breach); Schmid v. United States, 351 F.2d 65I, 654 (Ct. Cl. 1965) (interpretation).

${ }^{40} 168$ Ct. Cl. 522, 339 F.2d 606 (1964), modified, 34 U.S. LAW WEEK 4440 (U.S. June 6, 1966), 1965 DURE L.J. 654.

${ }^{50}$ This holding was recently reaffirmed in J. G. Watts Constr. Go. v. United States, 355 F.2d 573 (Ct. Cl. 1966) (by implication).
} 
Whether de novo evidence would be admitted where the issue decided administratively involved interpretation of the contract provisions was reserved in Utah. ${ }^{51}$ The court sought to answer this difficult question in Morrison-Knudsen Co. v. United States. ${ }^{52}$ Recognizing that "there is no one solution of the problem and that it is impossible to announce a rule that can be applied uniformly and without exception in every case in which a related question may be presented," "53 the court concluded that where relief is available under the contract and the dispute is within the jurisdiction of the administrative board "we deem it unwise to base the right to a trial de novo on the fact-law dichotomy." 54 Since complete relief was available to the contractor on a claim arising under the contract and within the scope of the "disputes" clause, "the action is not one for such a breach of the contract that entitles either party to a de novo trial on the factual questions decided.... [This is so] even when the major issue to be decided is a question of law ...."."55

The tone of the decision does not appear to sound absolute and unqualified. It may take an unusual case for the court to grant an exception but the possibility does not appear to have been completely foreclosed. Conceivably, a contractor who, for example, is able to convince the court that lack of compulsory process at the administrative level prevented him from developing his facts adequately may prevail on a plea for a de novo hearing. Furthermore, the Morrison-Knudsen decision does not foreclose the court from choosing from the record those facts it wishes to rely on, or from taking sub rosa judicial notice of matters not in the record. ${ }^{56}$

\section{Other Methods of Reversing Administrative Decisions}

When the administrative board fails to comply with its own procedures, ${ }^{57}$ or where procedures dictated by the contract are not

\footnotetext{
$51168 \mathrm{Ct}$. Cl. at 544, $339 \mathrm{~F} .2 \mathrm{~d}$ at $619-20$ (dissenting opinion). This question had also been reserved in Wingate Constr. Co. v. United States, 164 Ct. Cl. 131, 139 (1964) and WPC Enterprises, Inc. v. United States, 163 Ct. Cl. 1, 8-9, 323 F.2d 874, 878 (1963).

s2 170 Ct. Cl. 757, 345 F.2d 833 (1965).

${ }^{63} I d$. at 762,345 F.2d at $836-37$.

54 Id. at 762, 345 F.2d at 837 .

${ }^{55} I d$. at 764,345 F.2d at 837 . This holding was recently reaffirmed in Gholson, Byars \& Holmes Constr. Co. v. United States, 351 F.2d 987, 989 n.1 (Ct. Cl. 1965).

${ }^{58}$ See Tufano Contracting Corp. v. United States, 356 F.2d 535, 539 (Ct. Cl. 1966) (court noted trade practice in area). 1965).

"J7 Johnson v. United States, Gov'T Cont. REP. If 80115, at 85189 (Ct. Cl. Nov. 12,
} 
followed, ${ }^{58}$ the court will refuse to attach finality thereto. In addition, the court has very recently intimated that when administrative procedures are so substandard that they fail to meet the minimum due process standards of Morgan $v$. United States, ${ }^{59}$ this deficiency will be regarded as vitiating the administrative decision, and a de novo trial will be held. ${ }^{60}$ Where the line will be drawn in this regard must await further development. ${ }^{61}$

As a last resort, the court may utilize the inherent flexibility of the law-fact distinction or the substantial evidence rule. ${ }^{62}$ A few examples of this technique will afford adequate illustration.

In Gholson, Byars of Holmes Constr. Co. v. United States, ${ }^{63}$ the court stated its function to be "to review the administrative record before the Board to determine (1) whether its factual determinations meet the standards of the Wunderlich Act . . . and (2) whether its interpretation of the contract specifications is correct." ${ }^{4}$ Yet the court then found that "on the basis of the record before it, it must be concluded that the Board was in error in finding that plaintiff had failed to sustain its burden of showing the pre-work condition of the wall and ceiling surfaces." ${ }^{65}$ Thus, a clear overruling of a factual finding of the agency-the pre-work condition of the wall and ceiling-was accomplished by converting it into a question of law -whether plaintiff had sustained its burden in showing the condition. The court therefore held "as a matter of law that plaintiff is entitled to judgment under the 'Changes' clause of the contract for the additional expenses incurred in washing . . . those . . . surfaces....".66

In Blount Bros. Constr. Co. v. United States, ${ }^{67}$ the administrative board had considered a great amount of factual evidence. The court blithely stated that

\footnotetext{
"s Commercial Cable Co. v. United States, 170 Ct. Cl. 813, 820-22 (1965).

to 298 U.S. 468 (1936), 304 U.S. 1 (1938).

${ }^{\circ}$ Johnson v. United States, Gov'T CoNT. REP. I 80115, at 85189 (Ct. Cl. Nov. 12, 1965).

${ }^{\circ 1}$ For an indication of the possible flexibility of such an approach, see 1 DAvis, Administrative Law Treatise $\S \S 7.01-8.20$ (1958, Supp. 1965).

${ }^{82}$ An excellent treatment of this phenomenon can be found in 4 DAvis, ADMINISTRATIVE LAW TREATISE $§ \S 30.01-.14$ (1958, Supp. 1965).

c3 351 F.2d 987 (Ct. Cl. 1965).

os Id. at 989.

os Id. at 994. (Emphasis added.)

${ }^{80} \mathrm{Id}$. at 1001. (Emphasis added.)

o7 346 F.2d 962 (Ct. Cl. 1965).
} 
only one aspect of the Board's opinion which is significant to the resolution of the legal question can be characterized as a determination of a disputed factual issue, i.e. a symbol for concrete on the drawings. To the extent the Board relied on its finding on that point, its decision is unsupported by substantial evidence and must be rejected. The other factual findings of the Board are accepted .... We decide the legal issue on the basis of the Board's factual findings-except for the one finding, already mentioned, which we hold not to be adequately supported $\ldots .08$

The court thus chose one finding out of a number of findings, labeled it and no other as "significant," and "found" it to be "unsupported."

Often the two major themes illustrated above-law-fact and substantial evidence-are bound together. Thus, in Kings Electronic Co. v. United States ${ }^{69}$ the court faced a problem of whether a certain contract specification became applicable. If this constituted a question of law, the court said, "it is sufficient to state our belief that the Board was incorrect." "I0 If this was a question of fact, "we reach the same result, because the record shows that both parties considered [the] specification . . . to be applicable."71 Since the board had found the only relevant specification to be a different one, its decision "was not based upon substantial evidence"72_apparently by definition.

A variation can be found in Kaiser Indus. Corp. v. United States. $^{73}$ There it was found, through discovery proceedings before the court, that "erroneous" testimony had been presented to the agency, and hence " "we feel certain that if it had the evidence which we have ... it would have remanded the case to the contracting officer for a decision properly arrived at." "74 For this reason, the court held the agency's findings lacked " 'substantial support in the record as a whole." "75

This flexibility can work both ways, however. For example, in Chase of Rice, Inc. v. United States ${ }^{76}$ the court ostensibly side-

\footnotetext{
${ }^{68}$ Id. at 964 .

e 169 Ct. Cl. 433, 341 F.2d 632 (1965).

${ }^{70} \mathrm{Id}$. at $446,341 \mathrm{~F} .2 \mathrm{~d}$ at 640 .

${ }^{71}$ Id. at $446-47,341$ F.2d at 641 .

${ }^{72}$ Ibid.

73169 Ct. Cl. 310, 340 F.2d 322 (1965).

${ }^{74} I d$. at $334,340 \mathrm{~F} .2 \mathrm{~d}$ at 336 .

${ }^{75}$ Ibid.

${ }^{76} 354$ F.2d 318 (Ct. Cl. 1965).
} 
stepped the law-fact distinction by holding that regardless of whether a question of law or fact was involved, "this court in applying the most liberal or most stringent standard of review is in agreement with the Board's decision."'77 Where the court agrees with the agency, the subtle distinctions of law-fact and substantial evidence become meaningless.

\section{IV}

\section{Missing Facts and Remand Practices}

If determinations essential to a decision by the Court of Claims are missing from the administrative record, the possibility of remanding the case arises. The Court of Claims has a strong bias in favor of expediting litigation; ${ }^{78}$ hence, it is understandable that the court-in spite of the language in Bianchi which seems to favor relitigation at the administrative level ${ }^{79}$-has evolved rules which keep remands to the administrative agencies at a minimum.

Nevertheless, it should not be assumed that the court never remands cases; rather, instances of remand are simply hard to find since they apparently occur through routine intermediary orders. For example, two recent administrative decisions reveal that remands from the Court of Claims had occurred, in one instance for the purpose of conducting additional hearings with respect to certain reports considered by the board in arriving at its decision, ${ }^{\mathbf{8 0}}$ and in the other to pursue and complete the administrative remedy on an issue created by an amended administrative decision issued after commencement of suit in the Court of Claims. ${ }^{81}$

When the record is deficient in some respects but nevertheless contains sufficient information for the court to render a decision on the specific questions in issue, no remand will be ordered.82 The court has intimated, however, that it might remand a case even under these circumstances if credibility of witnesses could have a bearing on the decision. ${ }^{83}$

"7 Id. at 321. Cf. Terminal Constr. Corp. v. United States, Gov'T ConT. REP. ๆ 73059, at 63698 (Ct. Cl. 1965).

${ }^{78}$ For the reasons underlying this tendency, see Stein Bros. Mfg. Co. v. United States, 162 Ct. Cl. 802, 808-09, 337 F.2d 861, 863-64 (1963).

${ }^{70}$ See text accompanying note 14 supra and notes 85-86 infra.

${ }^{80}$ J. L. Simmons Co., 65-2 Bd. Cont. App. Dec. If 5266.

B2 Loral Electronics Corp., ASBCA No. 9174 (administrative proceedings on remand pending).

${ }^{82}$ E.g., C. J. Langenfelder \& Son v. United States, 169 Ct. Cl. 465, 476, 341 F.2d 600, 606 (1965).

${ }^{83}$ Gholson, Byars \& Holmes Constr. Co. v. United States, 351 F.2d 987, 995 n.7 
As has been pointed out previously, there are a number of situations in which the court has held that the contractor need not exhaust his administrative remedies before suing in the Court of Claims. ${ }^{84}$ In such a situation, since no record will exist for review, a necessary concomitant rule is that the court will determine the facts itself without a remand. ${ }^{85}$

When the court reverses an administrative decision, which in turn creates a need to determine the amount of damages, the cases clearly and uniformly hold that remand for that purpose will not be ordered, but that such determination will be made by the court itself. 88

A difficult situation occurs when the administrative adjudicators reject the plaintiff's claim on some threshold ground-such as lack of jurisdiction-and suit is then brought in the Court of Claims. Since the agency will not have reached any of the substantive issues, no record will exist for the court's review. In Anthony Grace of Sons $v$. United States ${ }^{87}$ the court clearly decided that it should not remand for factual findings in such a case. This holding was justified on the ground that a remand would not expedite the litigation, a goal contemplated even in Bianchi. ${ }^{88}$

Similarly, the Court of Claims did not remand but approved a de novo trial in a recent case where the administrative record was so deficient that it could not be properly reviewed. The Supreme Court in Bianchi, it will be recalled, had declared in a situation of this kind that two courses could be followed: The reviewing court could grant judgment without further administrative action, or it could stay its own proceedings pending further action before the

(Ct. Cl. 1965): "Suspension of the case to afford the Board opportunity to make findings on the issue would not serve any useful purpose inasmuch as the record was wholly documentary and the Board would thus not be in any special position to judge credibility." This passage is followed, however, by an alternative rationale: "Suspension, moreover, would delay still further a controversy that has already been the subject of inordinate delay."

${ }_{84}$ See part II A of this article.

${ }^{85}$ E.g., H. B. Zachry Co. v. United States, 170 Ct. Cl. 115, 122, 344 F.2d 352, 356.57 (1965).

${ }^{86}$ E.g., Aircraft Associates \& Mfg. Co. v. United States, 357 F.2d 373, 380 (Ct. Cl. 1966). Schmid v. United States, 351 F.2d 651, 655 (Ct. Cl. 1965); C. J. Langenfelder \&. Son v. United States, 169 Ct. Cl. 465, 486, 341 F.2d 600, 612 (1965); E. H. Sales, Inc. v. United States, 169 Ct. Cl. 269, 275, 340 F.2d 358, 361-62 (1965).

${ }^{87} 170$ Ct. Cl. 688, 345 F.2d 808, rev'd, 34 U.S. LAw WEEK 4437 (U.S. June 6, 1966).

${ }^{88}$ Id. at $694-95,345$ F.2d at 812-13. Judge Davis dissented to the majority's use of Bianchi for support of this holding. See $i d$. at 709-10, 345 F.2d at 821-22 (dissenting in part). 
agency involved. ${ }^{89}$ And in any case in which the department failed to remedy the particular substantive or procedural defect or inadequacy, the sanction of judgment for the contractor, said the Supreme Court, would always be available. ${ }^{90}$ The Court of Claims apparently did not consider these views of the Supreme Court as directory. In Roberts $v$. United States, ${ }^{91}$ the Secretary of the Smithsonian Institution appointed a special board to hear the dispute and make recommendations to him. The administrative proceedings were found to involve the following deficiencies: The record was such that the court could not determine what evidence outside of the record the board considered in preparing its report and recommendations; the failure of the board to provide for a transcript of the testimony made it impossible to ascertain the precise quantum of evidence which led the board to its conclusion; the refusal of the agency to furnish the contractor with a copy of its report and recommendations to the secretary until the Court of Claims action was started was improper; and there was a lack of quasi-judicial detachment and impartiality occasioned by the fact that the person who made the decision appealed from was also the contracting officer. ${ }^{92}$ These defects and improprieties led the Court of Claims to conclude that the administrative procedure was so deficient technically that the Wunderlich Act was not applicable, and the case was not remanded to the agency for corrective action. Instead, the Court of Claims held that the trial commissioner properly admitted de novo evidence.93 This retention of the case comports with earlier decisions of the Court of Claims to the effect that, without countervailing advantages, remands frequently would only add to the delay which the Supreme Court sought to diminish through its ruling. ${ }^{94}$

The remand practices of the Court of Claims are perhaps the most controversial aspect of its activity in this area. While the writer promised earlier not to become an advocate in this article, there is nevertheless a practical reason to support court retention which

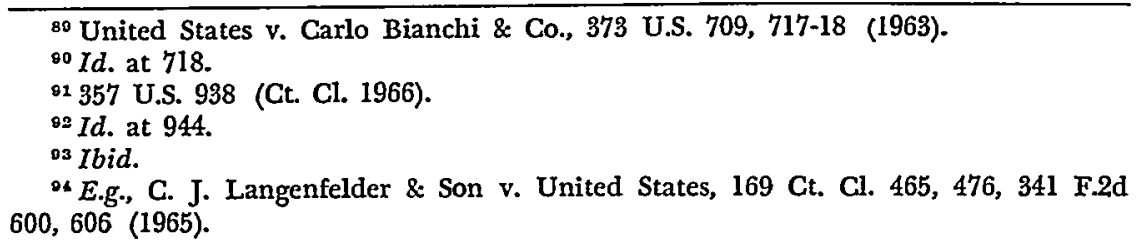


should be mentioned here, principally because it does not seem to have been considered or urged by others.

Some of the "disputes" clauses found in Navy and Corps of Engineers contracts provide for intermediary administrative appeals. ${ }^{95}$ If a case involving such intermediary appeal requirements were ultimately reversed by the court and had to be returned for additional administrative proceedings, to which administrative level should remand be made? And who would answer this question? The court has no power to order remands, ${ }^{90}$ and even if its wishes would be followed, it may not be familiar enough with the administrative system of adjudication to know which level could best rectify the deficiencies. Furthermore, it is not difficult to conceive that a contractor-after completing his first round of administrative remedies which resulted in judicial reversal on the merits-would have to pursue his administrative remedies through several levels all over again and then still be dissatisfied with the second result. This, in turn, would require him to sue again under the Wunderlich Act to right this grievance. In an area already so complex, any policy which serves the interests of expedition and simplification should be encouraged.

\section{$\mathrm{V}$}

\section{Statute of Limitations}

The Wunderlich Act unfortunately failed to shed any light on the operation of an applicable statute of limitations. This area is, therefore, still fraught with great uncertainty.

When suit is brought after the statutory period appears to have run, the contractor may make three arguments. First, he can contend that the cause of action did not accrue until the Government assumed a position contrary to his claim. This contention will probably not be upheld. "The rule that a claim based on a contract . . . first accrues ... 'when it can be definitely ascertained and set up, when all that is required of him by the terms of the contract has been fulfilled by the contractor,' is too well established to now attempt to controvert."97

\footnotetext{
${ }^{85}$ Authority for such procedures can be found in 32 C.F.R. $\$ \S 7.103 \cdot 12,7.203-12$ (1965).

${ }^{\circ}$ See United States v. Carlo Bianchi \& Co., 373 U.S. 709, 717 (1963); Anthony Grace \& Sons v. United States, $170 \mathrm{Ct}$. Cl. 688, 695, 345 F.2d 808, 812, rev'd, 34 U.S. LAW WEEK 4437 (U.S. June 6, 1966).

or Steel Improvement \& Forge Co. v. United States, 355 F.2d 627, 630 (Ct. C1. 1966).
} 
Secondly, the contractor can argue that the cause of action does not accrue until administrative procedures have been exhausted, for until that time he has no perfected claim. While this argument seems somewhat persuasive-at least where the dispute turns on questions of fact-it has been expressly rejected by the Supreme Court ${ }^{98}$ and will probably be unsuccessful for the reasons given in the preceding paragraph.

Thirdly, a claim can be made that the statute is tolled during pursuit of any applicable administrative remedies. This contention was successful in the recent case of Northern Metal Co. v. United States, ${ }^{02}$ but the Third Circuit was careful to point out that the statute would not be tolled during any period of delay by the contractor in pursuing his administrative remedies-only during actual pendency before the contracting officer or the appellate board would tolling occur. ${ }^{109}$ In addition, the Court of Claims has recently affirmed that "it is only when pursuance of administrative remedies is a prerequisite to suit that the statute of limitations is suspended or tolled by such pursuance."101 Presumably this would mean that whenever plaintiff's suit was for breach of contract, the statute would not be tolled.

In all cases of doubt, the safe practice for the contractor to follow is to file a "protective lawsuit" while concurrently pursuing the administrative remedies. ${ }^{102}$

VI

Additional Holdings by the Supreme Court

While this article was being written, the Supreme Court handed down decisions in two cases previously discussed-Utah Constr. b Mining Co. v. United States ${ }^{103}$ and Anthony Grace \& Sons v. United States. ${ }^{104}$

The Supreme Court appears to favor the idea that fact determination functions under "disputes" clauses properly fall within ad-

\footnotetext{
${ }^{\circ 8}$ McMahon v. United States, 342 U.S. 25 (1951).

00350 F.2d 833 (3d Cir. 1965).

${ }^{100}$ Id. at 839.

${ }^{101}$ Steel Improvement \& Forge Co. v. United States, 355 F.2d 627, 631 (Ct. Cl. 1966).

${ }^{102}$ States Marine Corp. v. United States, 283 F.2d 776, 779 (2d Cir. 1960); John P. Moriarty, Inc. v. United States, 97 Ct. Cl. 338, 340-41 (1942).

${ }^{103} 168$ Ct. Cl. 522, 339 F.2d 606 (1964), modified, 34 U.S. LAW WEEK 4440 (U.S. June 6, 1966), 1965 Duke L.J. 654.

${ }^{106} 170$ Ct. Cl. 688, 345 F..2d 808, rev'd, 34 U.S. LAW WEER 4437 (U.S. June 6, 1966).
} 
ministrative competence and that duplication of evidentiary hearings should be avoided. As anticipated, the Utah case was modified so as to make administratively-determined facts that are relevant and appropriate in a controversy arising under the contract and within the scope of the "disputes" clause fully binding even in a controversy arising outside the contract-at least to the extent that such findings are directly applicable to the outside controversy. In order to be conclusive, however, such findings will still have to meet the criteria of the Wunderlich Act. In addition, to the extent that any issues could be labeled as being outside of the contract and "disputes" clause, and involving facts which have not been passed upon administratively, it would seem to follow that a court having jurisdiction could take evidence and decide all factual disputes itself.105

The Grace case was not remanded because the Court of Claims, in effect, equated the dismissal for untimeliness with decisions which held that failure of a contracting officer or contract appeals board to act administratively allowed immediate recourse to the courts. ${ }^{108}$ There was considerable doubt as to whether the Supreme Court would accept this analogy. It was rather more likely for the Supreme Court, in accordance with the Grace dissent, ${ }^{107}$ to rule that an erroneous dismissal by an administrative agency is not equivalent to a refusal to consider the merits and, therefore, that courts should remand these cases to the administrative agencies to pass upon the disputes in the first instance. As Grace was reversed, it will cast a shadow on the propriety of other Court of Claims decisions referred to in this article which followed the course of retention rather than remand.

One thing is certain. The Court of Claims has shown itself to be a strong and independent court. The gradual demise of influence -except for its strict holding-of the Supreme Court's decision in Bianchi is a clear indication of the future fate of recent Supreme Court holdings in Utah and Grace which impose limitations that

${ }^{105}$ By way of illustration, see Universal Transistor Prods. Corp. v. United States, 214 F. Supp. 486 (E.D.N.Y. 1963). After an adverse administrative decision on an appeal seeking relief from the imposition of reprocurement costs incident to a termination of the contract for default, the contractor brought suit for rescission of the contract on the ground that the Government failed to notify it of the "ruinously low bid" it had submitted. In denying a motion to dismiss, the court set the case down for trial, stating that "in the present posture of this case, the Court has power to and must determine de novo this question of rescission." Id. at 488 .

${ }^{108}$ Anthony Grace \& Sons v. United States, 170 Ct. Cl. 688, 692-95, 345 F.2d 808, 810-12, rev'd, 34 U.S. LAW WEEK 4437 (U.S. June 6, 1966).

${ }^{102} \mathrm{Id}$, at 709-12, $345 \mathrm{~F}, 2 \mathrm{~d}$ at $821-23$ (Davis, J., dissenting in part). 
would hamper judicial review by the Court of Claims at the operating level. Realizing this, a contractor should not fail to utilize the full panoply of review opened to him by the Court of Claims. Whether this broad scope of review is wise or unwise is immaterial. Its existence can hardly be doubted. 